\title{
Gençlerin Erişkin Başlangıçıı Diyabeti (MODY) Sorumlu HNF4A, GCK ve HNF1A Gen Varyasyonlarının Dünya Genelinde Coğrafik Dağılımı
}

\author{
Deniz KANCA DEMIRCí ${ }^{1 *}$, Nurdan GÜL ${ }^{2}$, Ilhan SATMAN ${ }^{2}$, \\ Oğuz ÖZTÜRK ${ }^{3}$, Hülya YILMAZ AYDOĞAN ${ }^{3}$
}

${ }^{1}$ Haliç Üniversitesi, Fen-Edebiyat Fakültesi, Moleküler Biyoloji ve Genetik Bölümü, İstanbul, Türkiye.

2 İstanbul Üniversitesi, İstanbul Tıp Fakültesi, İç Hastalıkları AD, Endokrinoloji ve Metabolizma Hastalıkları BD, İstanbul, Türkiye.

3 İstanbul Üniversitesi, Aziz Sancar Deneysel Tıp Araştırma Enstitüsü, Moleküler Tıp AD, İstanbul, Türkiye.

Orcid: 0000-0003-2728-7323, 0000-0002-1187-944X, 0000-0001-8613-1797, 0000-0002-2439-9269, 0000-0002-8837-6664

*Sorumlu Yazar e mail: denizkanca@halic.edu.tr

Geliş Tarihi: 12.02 .2021

Kabul Tarihi: 11.03.2021

Atıf/Citation: Kanca Demirci, D., Gül, N., Satman, I., Öztürk, O., Yılmaz Aydoğan, H. “Gençlerin Erişkin Başlangıçlı Diyabeti (MODY) Sorumlu HNF4A, GCK ve HNF1 Gen Varyasyonlarının Dünya Genelinde Coğrafik Dağılımı”, Haliç Üniversitesi Fen Bilimleri Dergisi 2021, 4/1: 41-68.

Derleme Makalesi/ Review Article

\section{Özet}

Gençlerin Erişkin Başlangıçlı Diyabeti (MODY) otozomal dominant kalıtım ile karakterize monogenik bir hastalıktır. Şimdiye kadar 14 farklı gende çok sayıda heterozigot mutasyon tanımlanmış olup bu mutasyonların dağılımı her ülkede farklıdır. Çalışmamızda yaygın MODY alt tipleri, MODY1-3, için literatür araştırması yaparak HNF4A, GCK ve HNF1A genlerindeki yanlış anlamlı mutasyonları özetledik. Ancak Asya populasyonlarında bilinen MODY genleri bu diyabetik bireylere tanı koymak için yeterli olmayıp çoğu MODYX olarak tanımlanmaktadır. Dahası, Avrupa ülkeleri ile kıyaslandığında Çin, Japonya, Kore ve Hindistan populasyonlarında MODY prevalansında çelişkiler mevcut olup hastalığın genetik alt yapısının daha iyi anlaşılması için daha fazla genetik çalışmaya ihtiyaç duyulmaktadır.

Anahtar Kelimeler: MODY, HNF4A, GCK, HNF1A 


\title{
Geographical Distribution of HNF4A, GCK and HNF1A Gene Variations Responsible for Maturity-Onset Diabetes of the Young (MODY) Worldwide
}

\begin{abstract}
Maturity-onset diabetes of the young (MODY) is a monogenic diabetes form which is characterized by autosomal dominant inheritance. To date, numerous heterozygous mutations in 14 different genes have been identified and the distribution of these mutations are different in every country. In this study, we investigated the literature for the most common MODY subtypes, MODY1-3, and summarized the common missense mutations in HNF4A, GCK and HNF1A genes. However, in Asian populations known MODY genes are not enough to diagnose these diabetic patients and most of them are diagnosed as MODYX. Moreover, there is a discrepancy for the prevalence of MODY in China, Japan, Korea and India populations compared to European countries and more genetic study is needed to understand the genetic background of this disease.
\end{abstract}

Keywords: MODY, HNF4A, GCK, HNF1A

\section{Gençlerin Erişkinlik Başlangıçlı Diyabeti (MODY)}

Diabetes mellitus (DM) insülin sekresyonundaki bozukluklar veya insülin direnci sonucu gelişen hiperglisemi ile karakterize kronik ve metabolik bir hastalıktır. Altta yatan etkene bağlı olarak tip 1, tip 2 ve gestasyonel diyabet olarak üç ana gruba ayrılmaktadır [1]. Buna ilaveten, ilk kez Tattersall (1974) tarafından ailesel, insüline bağımlı olmayan, çocuk ve genç yetişkinlerde görülen bir formu tespit edilmiştir [2] . "Gençlerin Erişkin Başlangıçlı Diyabeti (MODY)" olarak tanımlanan bu yeni diyabet formu tek gende otozomal dominant mutasyonlarla beta hücrelerinde fonksiyon bozukluğuna yol olmaktadır [3]. MODY klinik tanısı az üç nesil benzer glisemik paternli otozomal dominant kalıtım, 25 yaş öncesi tanı, pankreatik otoantikorların yokluğu, endojen insülin üretiminin devam etmesi ve hiperglisemi varlığında ölçülebilir C-peptid düzeyleri, düşük komplikasyon ve metabolik bozukluk (obezite) oranı ve ketoasidoz görülmemesi gibi özelliklere göre yapılmaktadır [3-8]. Bu özellikler tip 1 diyabet için atipiktir. Ancak erken 
yaşta başlaması tip 1 diyabet ile örtüşmektedir. Tip 2 diyabetiklerde ise obezite ve akantozis nigrikans yokluğu, normal trigliserid düzeyleri ve normal veya artmış yüksek yoğunluklu lipoprotein (HDL) kolesterol düzeyleri ile karakterize insülin direncinin gözlenmemesi monogenik diyabeti düşündürmektedir [6]. Bu nedenle, MODY kesin tanısı için MODY genlerinin dizilenmesi gereklidir [9].

MODY, beta hücre gelişimi ve fonksiyonunu etkileyen genlerdeki fonksiyon kaybı mutasyonları ve buna bağlı gelişen haployetersizlik sonucu gelişmektedir [7]. MODY genleri, glukoz metabolizmasında, insülin veya glukoz taşınmasında ve fetal pankreas gelişiminde görev alan diğer genlerin düzenlenmesinde rol alır. $\mathrm{Bu}$ genlerin anlatımı karaciğer ve böbrek gibi dokularda da yapıldığ 1 için bazı MODY formlarında karaciğer ve böbrek fonksiyon bozuklukları da gözlenmektedir. İnfeksiyon, puberte, gebelik ve obezite gibi insülin duyarlılı̆̆ını etkileyen faktörler MODY'nin başlamasını tetikleyebilir veya MODY hastalarında hiperglisemi şiddetini artırabilir [10].

Mutasyonların karakterine ve çevresel koşullara göre genetik, metabolik ve klinik heterojenite gösteren MODY'nin klinik özellikleri ve prevalansı farklı etnik gruplarda değişiklik göstermektedir [6, 1113]. Monogenik alt yapısına rağmen aile içi fenotipik farklılıklar bir MODY tipinin aynı genin çeşitli mutasyonlarından geliştiğine işaret etmektedir [12]. Bununla birlikte aynı ailede farklı MODY tiplerine rastlamak da mümkündür [14].

MODY sınıflandırması başlangıç yaşı, tedaviye yanıt durumu, pankreas dişı özellikler, hiperglisemi şiddeti, komplikasyonlar ve fenotipik çeşitliliğe göre yapılmaktadır [3]. Günümüzde MODY'nin beta hücre fonksiyonlarını etkileyen, çoğu transkripsiyon faktörlerini, diğerleri de glukokinaz ve karboksil ester lipaz gibi enzimleri veya iyon kanal proteinlerini kodlayan 14 farklı gendeki mutasyonların MODY etyopatogenezinde rol oynadığı bilinmektedir [15-17]. Sirasıyla hepatosit nükleer faktör 4A (HNF4A), glukokinaz (GCK), hepatosit nükleer faktör 1A (HNF1A), insülin promotor faktör (IPF-1), hepatosit nükleer faktör 1B (HNF1B), nörojenik farklılaşma faktörü 
(NEUROD1), Kruppel benzeri faktör 11 (KLF11), karboksil ester lipaz (CEL), Eşleştirilmiş kutu 4 (PAX4), insülin (INS), B lenfosit kinaz (BLK), ATP-bağlayıcı kaset taşıyıcı C alt ailesi üye 8 (ABCC8), içeri doğrultucu potasyum kanalları J alt ailesi üye 11 (KCNJ11) ve adaptör protein, $\mathrm{PH}$ alanı ve lösin fermuar 1 ile etkileşen fosfotirozin (APPL1) genlerindeki heterozigot varyasyonlar ile MODY 1-14 alt tipleri tanımlanmaktadır $[15,16]$.

MODY hastaları sıklıkla diyet ve sülfonilüre ajanları ile tedavi edilirler. Ancak bazı formlarında oral antidiyabetik ajanlar ve insülin de kullanılmaktadır [15].

HNF1A, GCK ve HNF4A mutasyonları dünyada en yaygın MODY alt tipleri olup vakaların \%90'ını oluşturmaktadır [8]. Diğer formları ise daha nadirdir. MODY1-3 alt tipleri çalışılan çoğu populasyonda en yaygın MODY alt tipi olarak gözlenmesine rağmen GCK/HNF1A oranı, genetik test çalışma dizaynlarındaki farklılıklardan dolayı hem populasyonlar arasında hem de aynı populasyonda farklı araştırıcılar tarafindan yapılan çalı̧̧malarda değişkenlik gösterebilmektedir [18]. Örneğin, Avrupa'da İngiltere, Hollanda, Norveç ve Danimarka'da MODY3 yaygın iken (MODY3>MODY2>MODY1), İtalya, Fransa, Almanya, Polonya, Çek Cumhuriyeti, İspanya, Yunanistan'da MODY2 daha yaygındır (MODY2>MODY3>MODY1) (Şekil 1) $[8$, $19,20]$. Çek populasyonunda ise rutin olarak yaygın MODY1-6 sorumlu genler test edilmesine rağmen tanı alamayan MODYX vakaları bildirilmiştir [21].

Avrupa'da MODY mutasyonları sık çalışılmış ve prevalansları belirlenmişken, Asya ülkelerinde kesin prevalansları henüz belirlenememiştir (Şekil 1). Bu durum hem MODY vaka sayılarının kısıtlı olmasından hem de özellikle Çin ve Japonya'da tanımlı MODY genlerinin bu toplumlardaki vakaları açıklamada yetersiz kalmasından kaynaklanmaktadır [15, 20, 22-26]. Çin'de MODY vakalarının \%9'unun MODY3 ve \%1'inin MODY2 mutasyonları ile geliştiği rapor edilse de [26] son yapılan çalışmalar Çin MODY hastalarının \%80'inin genetik alt yapısının açıklanamadığını ortaya koymaktadır [27-29]. 
Japonya'da yürütülen çalışmaların sonuçları da Çin'dekilere benzer olup MODY3'ün MODY2'den yaygın olduğu (MODY3>MODY2>MODY1) bildirilmiştir [20, 26, 30-33]. Kore'de de diyabetik vakalarin ancak \%10'u bilinen MODY genleri (HNF1A: \%5, GCK: \%2,5 ve HNF1B: \%2,5) ile tanımlanabilmektedir [34]. Ancak MODY vakalarının çok az bir kısmının bilinen MODY genleri ile tanımlanabiliyor olması Kore, Japonya ve Çin'de MODY vakalarının büyük çoğunluğunun MODYX olarak tanımlanmasına yol açmaktadır [26, 30-33, 35-37]. Benzer şekilde Brezilya'da da MODY vakalarının bir kısmı HNF1A ve GCK varyasyonlarını taşımaktayken, diğerleri MODYX olarak tanı almaktadır [38]. Bu çelişkili durumu çözmek için yeni nesil dizileme teknikleri ile daha çok geni dizileyerek sorumlu gen ve mutasyonları tespit etmek gereklidir [33, 36, 37, 39].

Yapılan çalışmalar Asya populasyonlarında HNF1A varyantlarının tanımlanabilen MODY vakaları arasında yaygın olduğuna işaret etmektedir [40]. Ancak Asya, Afrika, Güney Amerika ve Orta Asya populasyonlarında MODY prevalansı bilinmemekte ve Avrupa dışı bölgelerde genetik çalışmalarının yapılması önem kazanmaktadır [17, 40]. Nitekim son çalışmalar MODY gelişiminden sorumlu olduğu düşünülen yeni genlerin (MYO5A, c-Myc, CDK4, ARHGDIA, NKX61, PTPRD, SYT9 and WFS1) varlığına işaret etmektedir [15, 28, 41, 42].

Dünyada ve ülkemizde HNF4A, GCK ve HNF1A genlerinde yapılan çalışmalarda MODY etken olarak bildirilen yanlış anlamlı varyasyonlar ise Tablo 1'de özetlenmiştir. Buna göre, Amerika kıtasında ABD ve Kanada'da MODY1-3 alt tipleri, Meksika'da MODY1 ve Brezilya'da MODY1 ve MODY3 vakaları, Asya kitasında Kore'de MODY1 ve MODY3, Japonya, Çin, Hindistan ve İran'da MODY2 ve MODY3 vakaları bildirilmiştir. Avrupa'da ise her üç MODY tipine de rastlanmakta ve Şekil 1'de de görüldüğü üzere MODY dağılımları ülkeler arasında değişiklik göstermektedir. Üstelik genetik farklılıklar aynı ailede farklı MODY mutasyonlarının olmasına benzer şekilde aynı coğrafik bölgede bulunan ülkelerde de göze çarpmaktadır. Buna 
karşılık bazı varyantlar gen üzerindeki etkilerinin şiddeti ile hastalığın patogenezine olan katkısı sayesinde farklı populasyonlarda gözlenmektedir. Ülkemiz dahil MODY dağılımındaki bu farklılıklar hastalığın heterojen genetik alt yapısını desteklemektedir. Bu durum, hastal1ğın etyopatogenezinin daha iyi anlaşılabilmesi için yeni nesil dizileme teknikleri ile geniş çalışma gruplarında genetik analizler yapılması gerektiğine işaret etmektedir. Detaylı genetik testler ile hastalığın tanı alması aynı zamanda bu hastalara uygun tedavi protokollerinin önerilmesini ve aile bireylerinin de diyabetik risk için bilgilendirilmesini sağlayacaktır.

\section{Sonuçlar}

MODY, tek gen mutasyonlarına bağlı olarak ortaya çıkan ve örtüşen özellikleri nedeniyle sıklıkla tip 1 ve tip 2 diyabet olarak yanlış tanı alan genetik ve metabolik bir hastalıktır. Hastalığın gelişiminde rol alan genetik faktörlerin açığa çıkarılması hastalara doğru tedavi yöntemleriyle yaklaşılması açısından önemlidir. Ancak son yapılan çalışmalar klinik ve genetik alt yapısı heterojen olan bu hastalıkta şimdiye kadar tanımlanan MODY genlerinin tüm MODY vakalarını açıklamada yetersiz olduğuna işaret etmektedir. Bu nedenle, genetik testler ile yeni MODY sorumlu genlerin ve varyasyonların tespiti hastalığın patogenezini ve gerçek prevalansını belirlemek için elzemdir. 


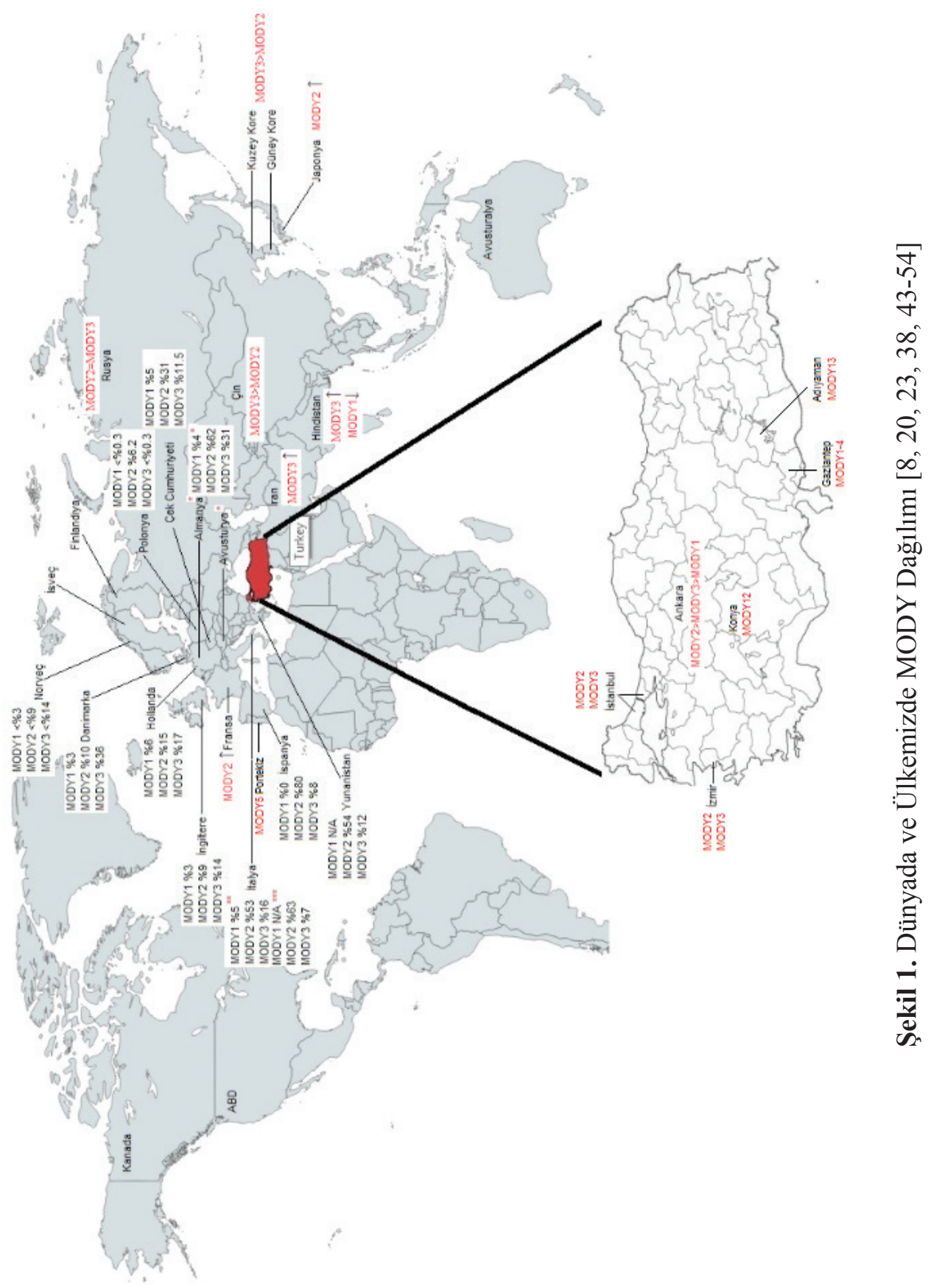




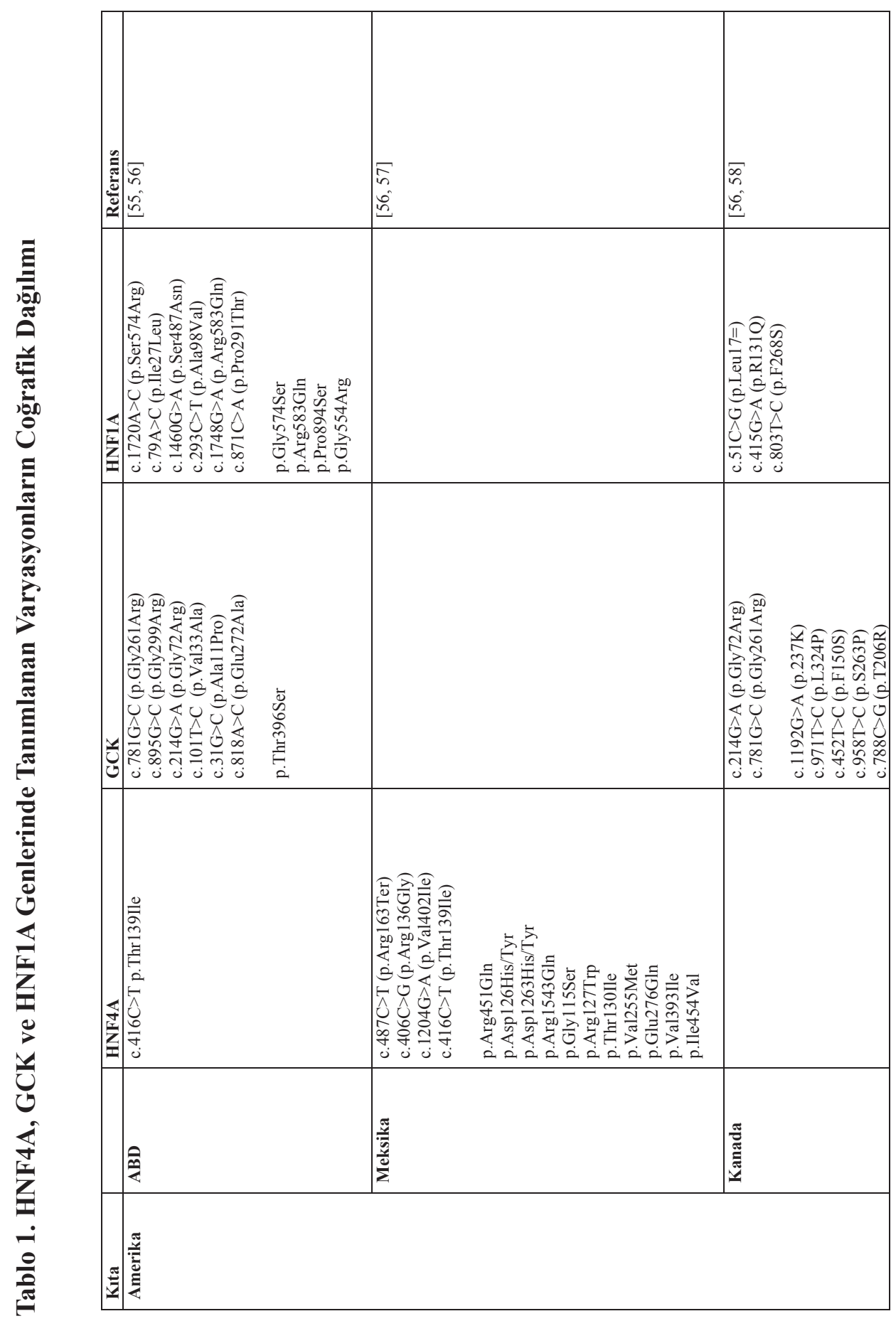




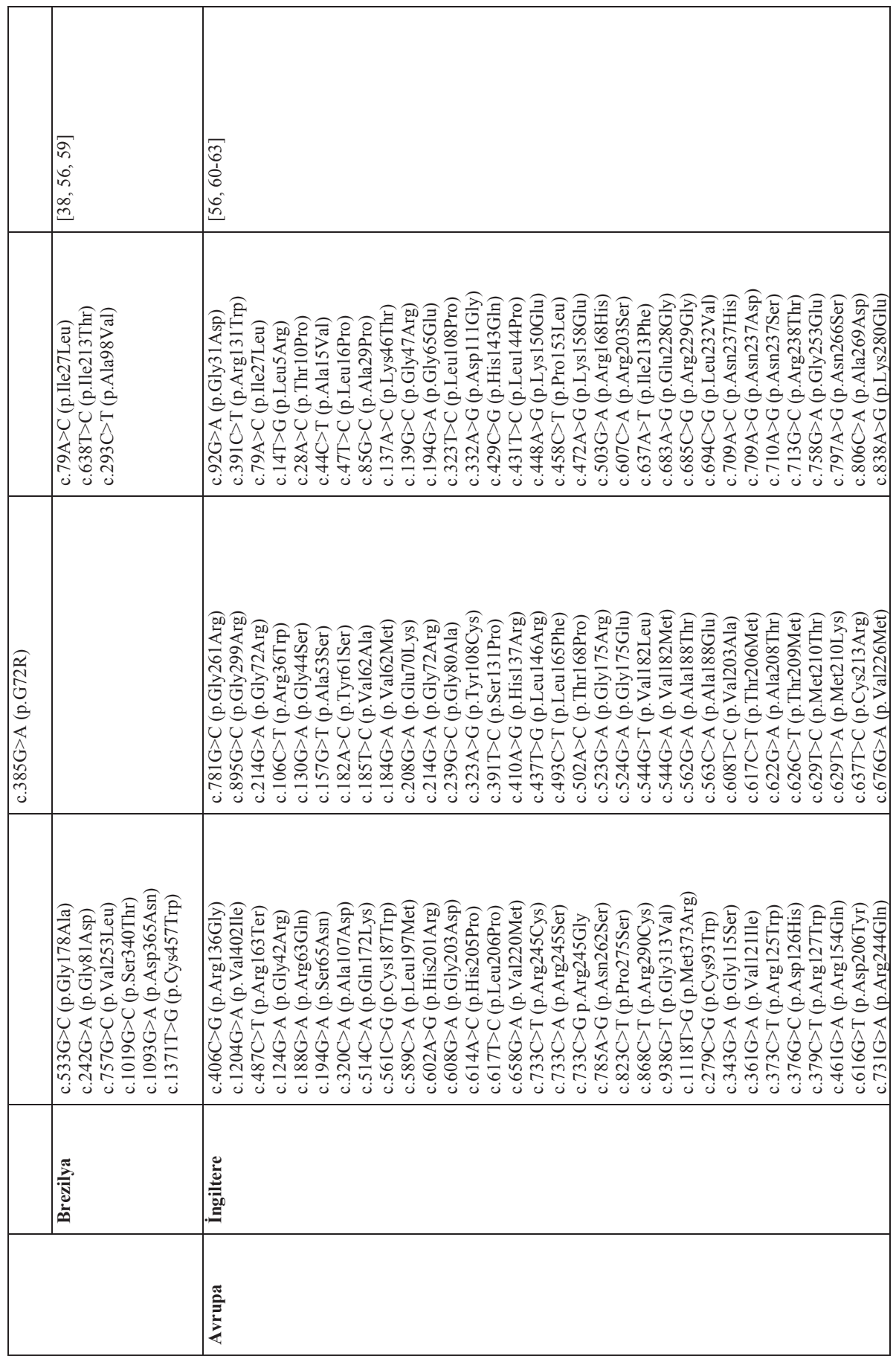




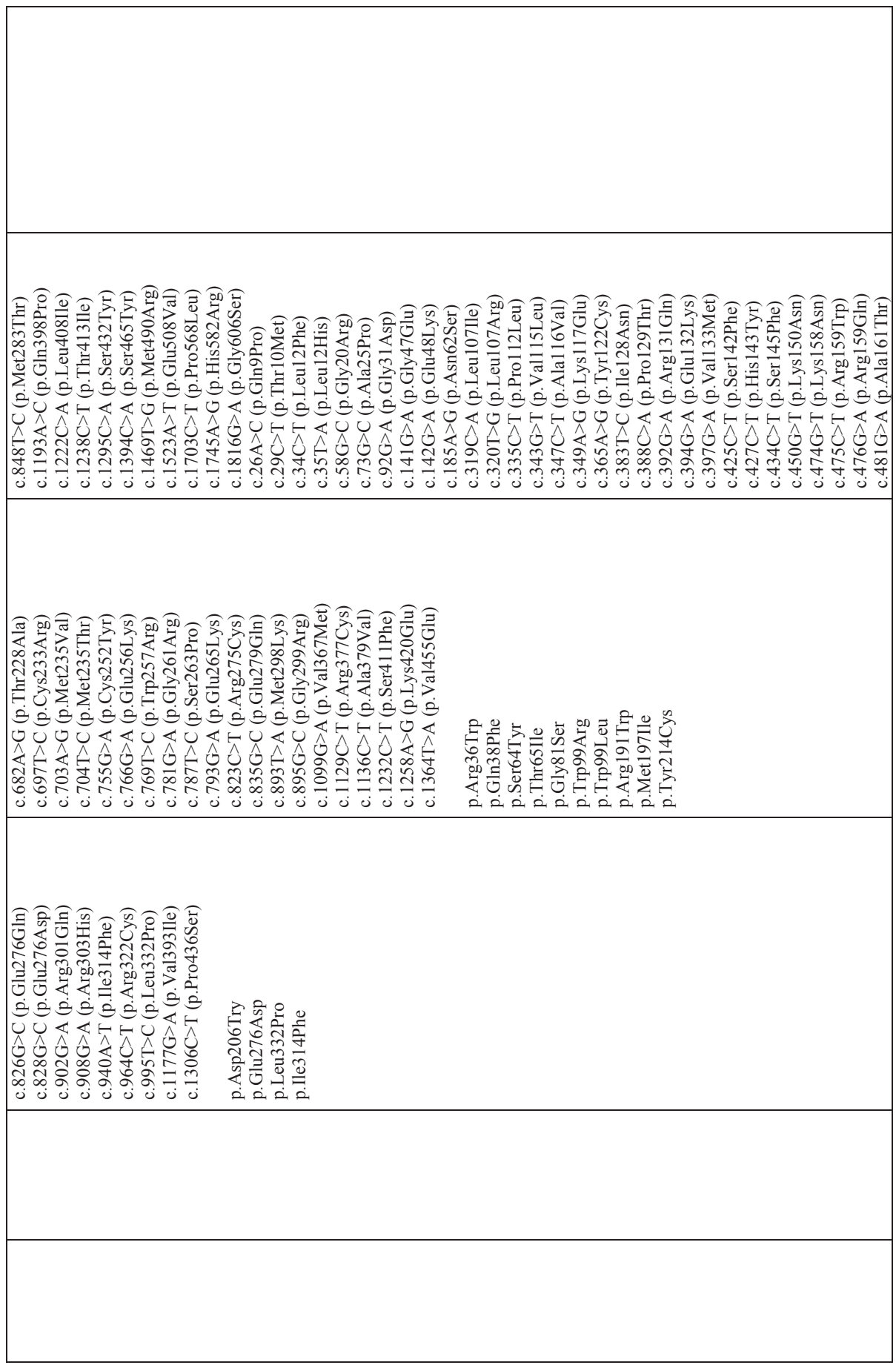




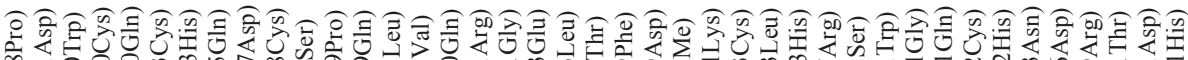
o

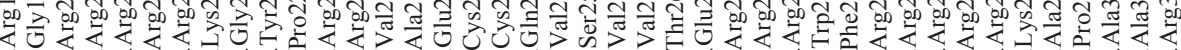

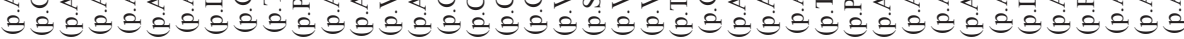
U

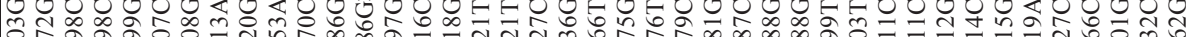

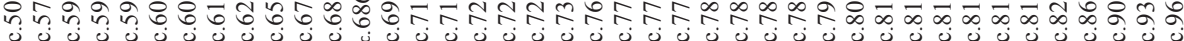

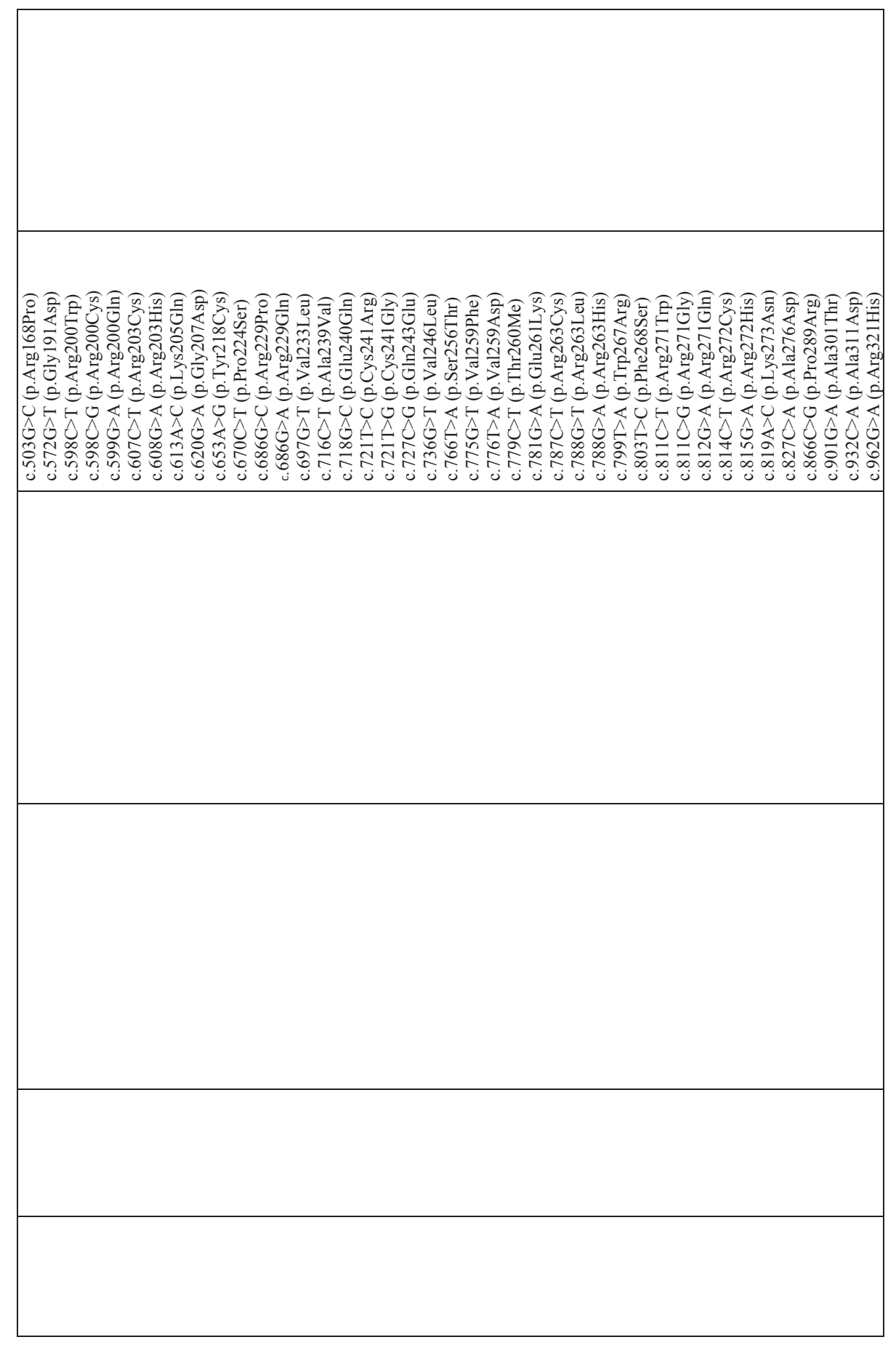




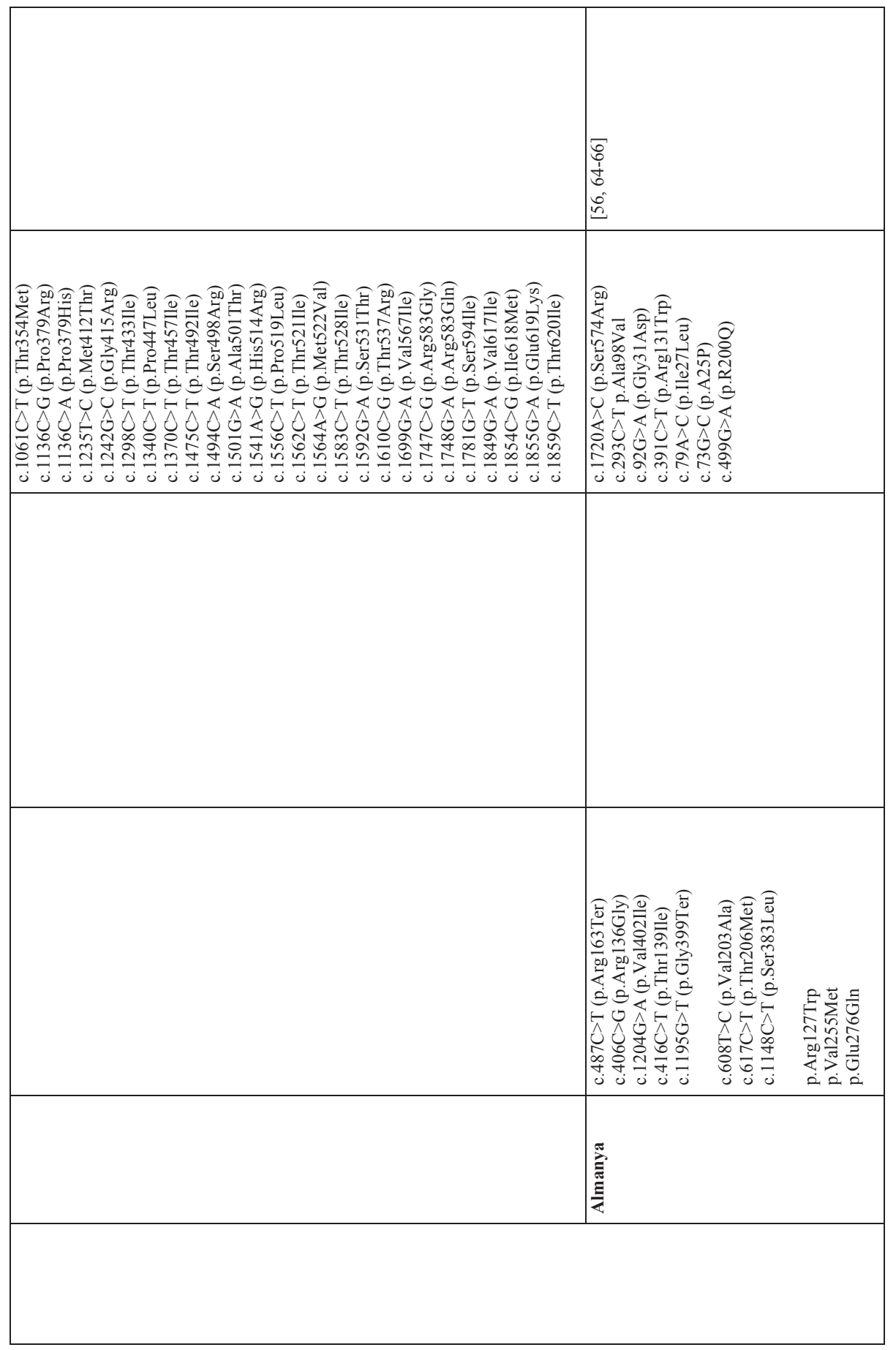




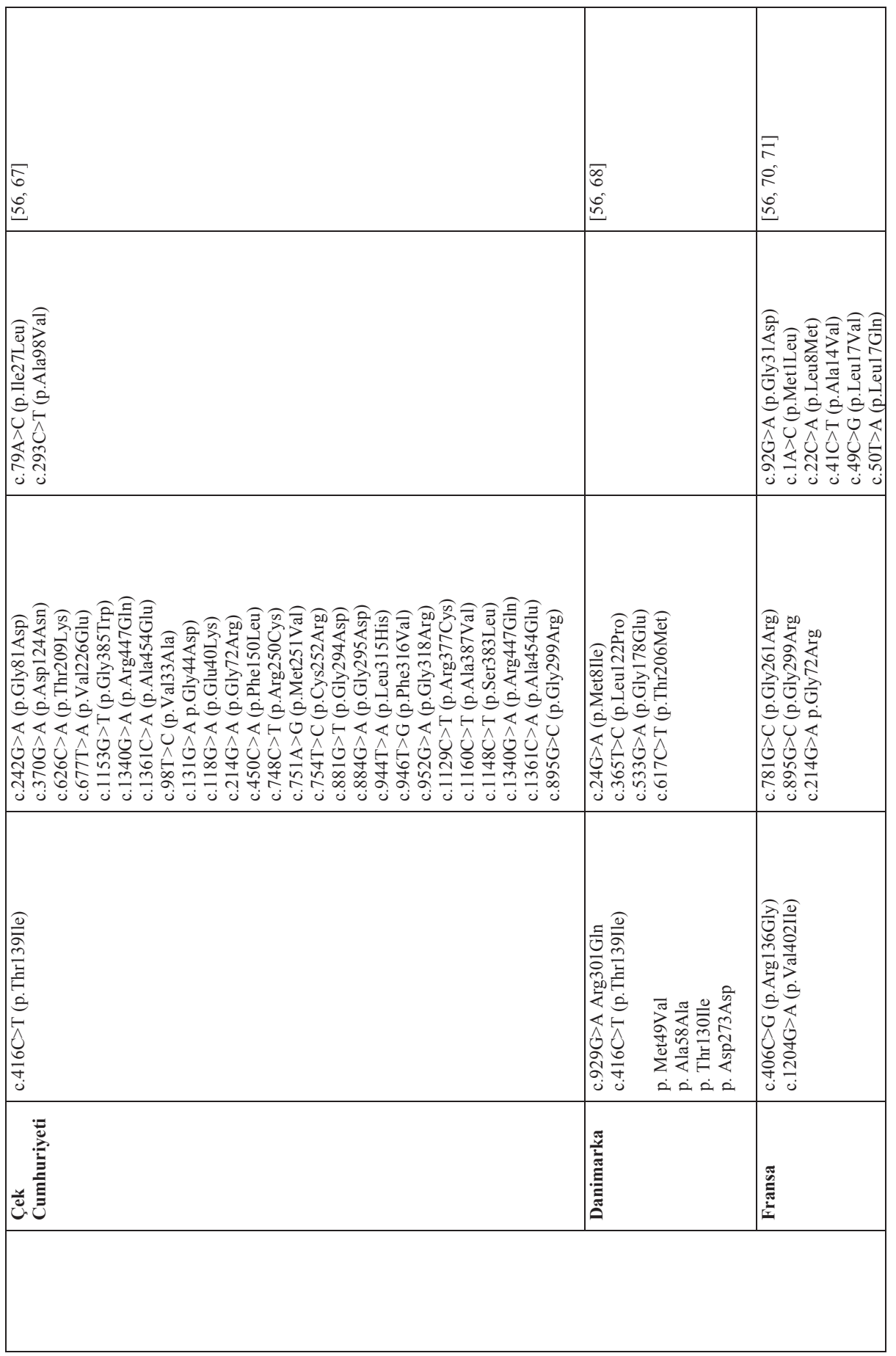




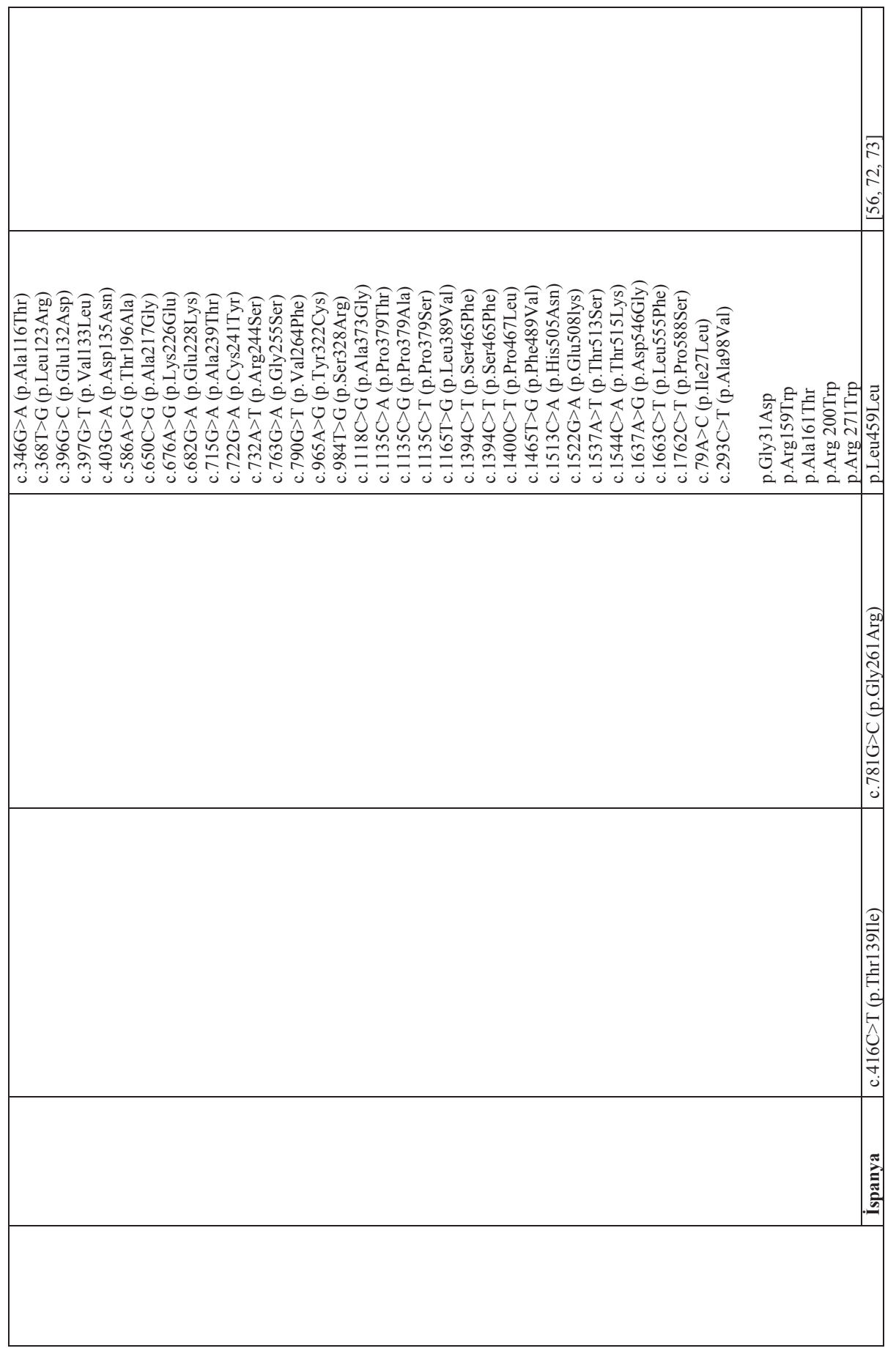




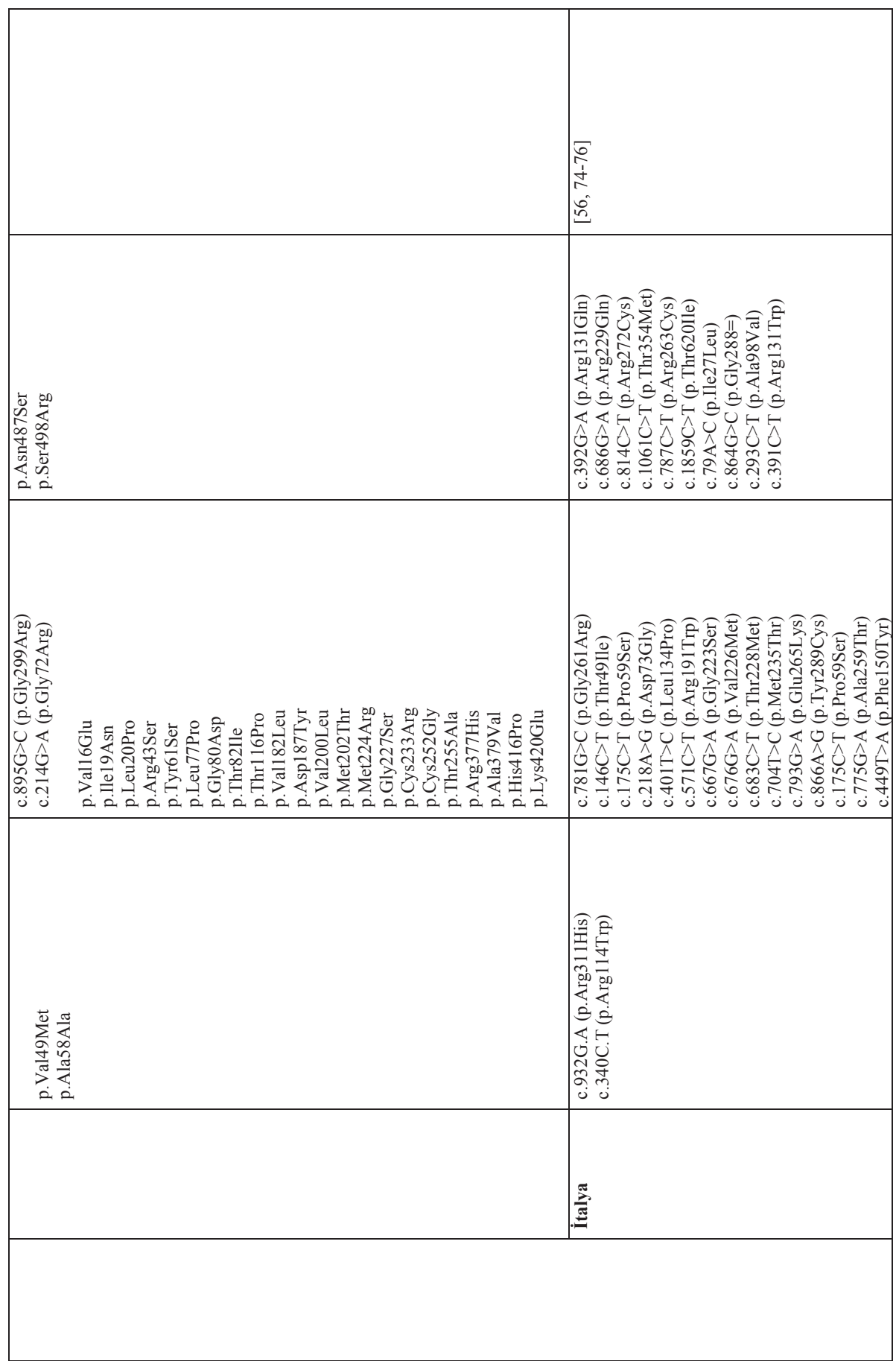




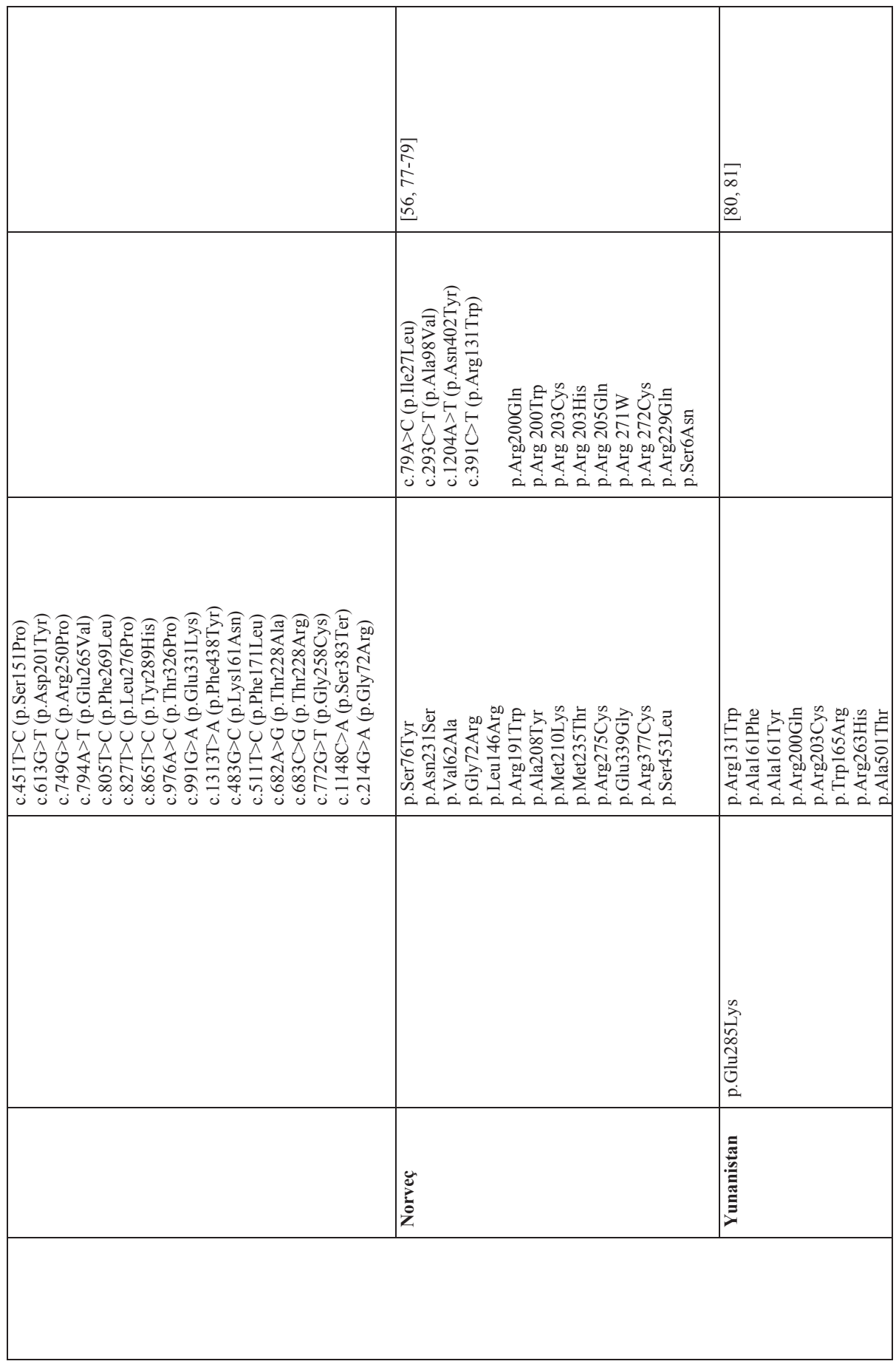




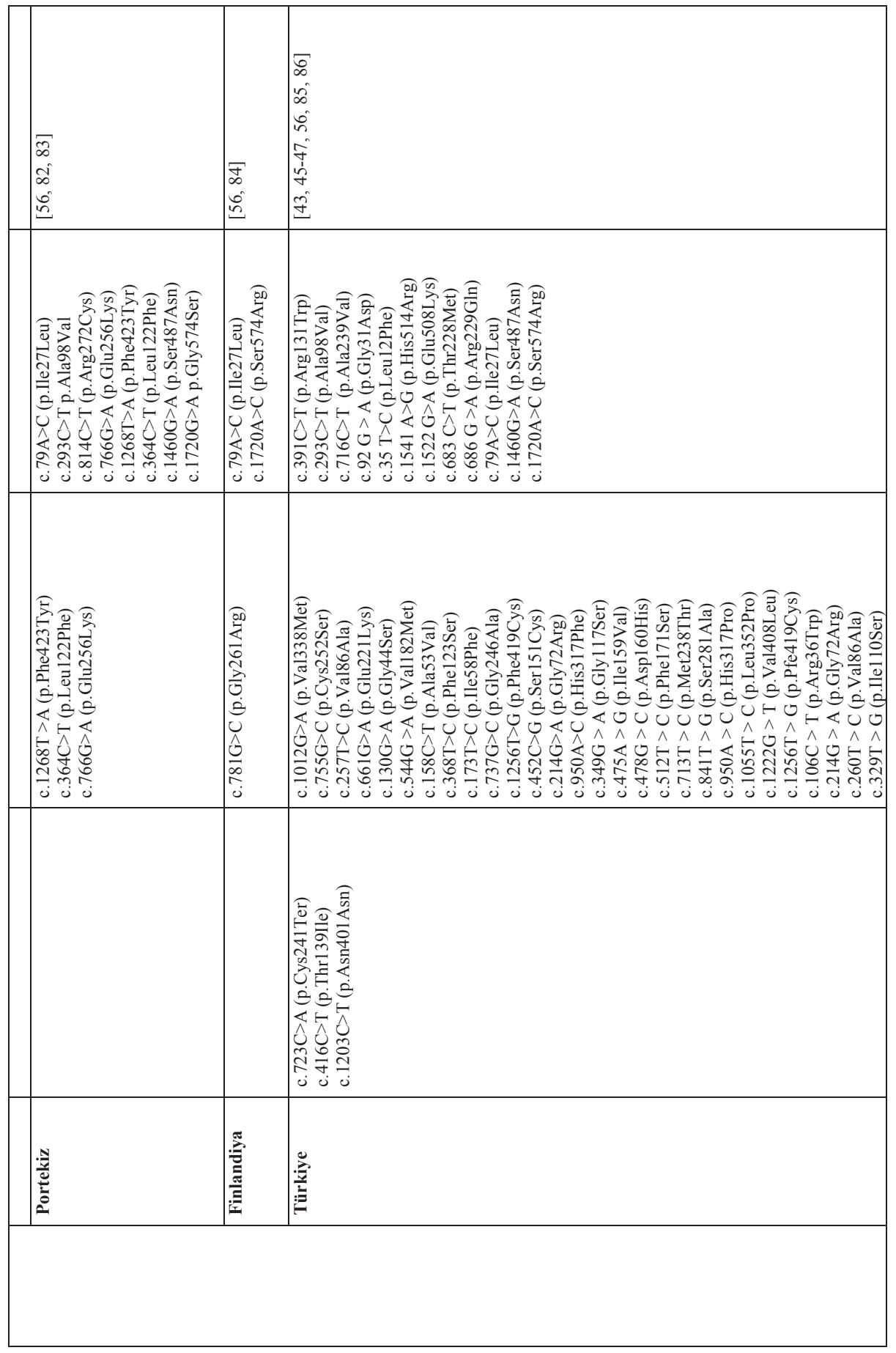




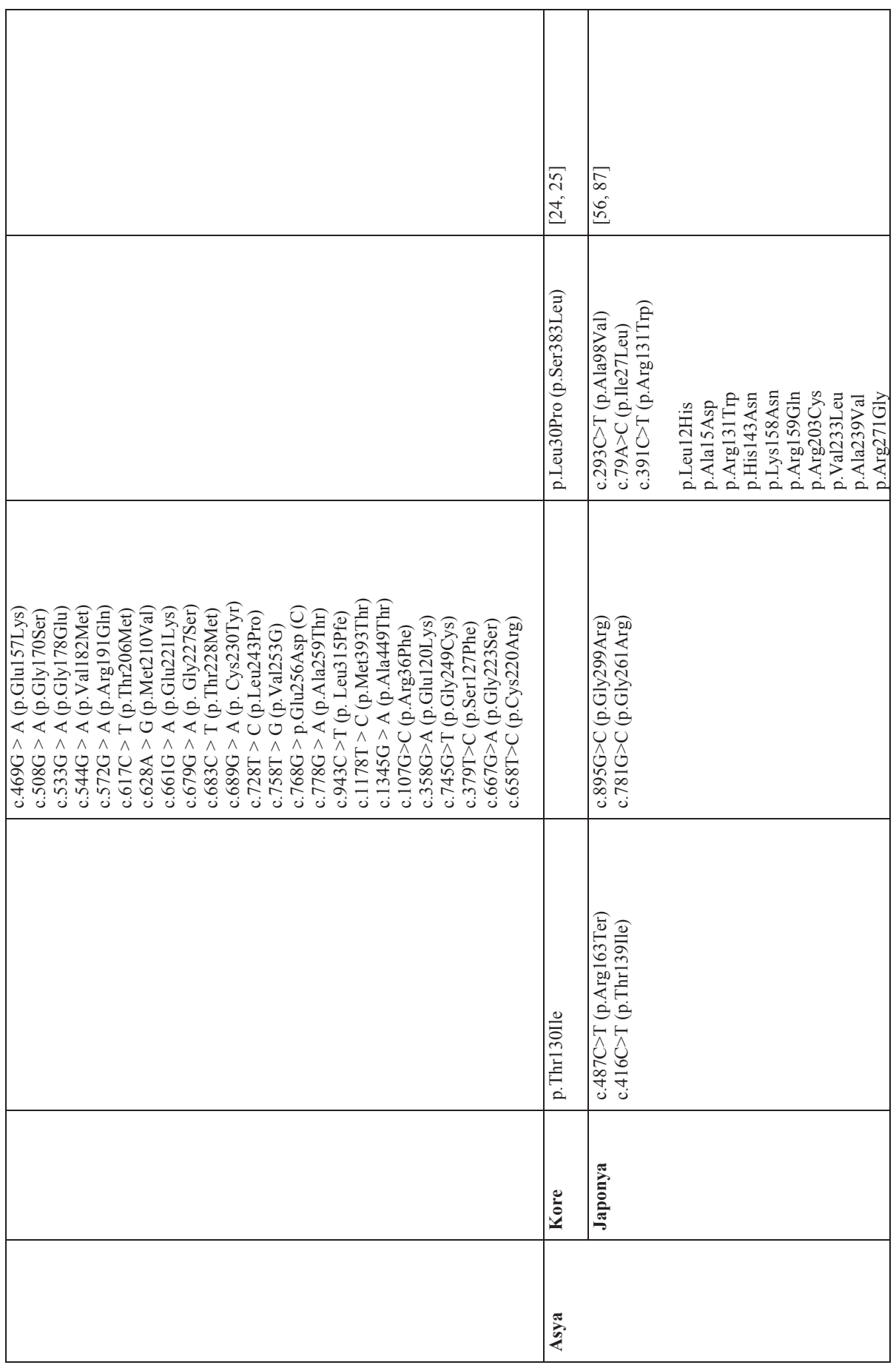




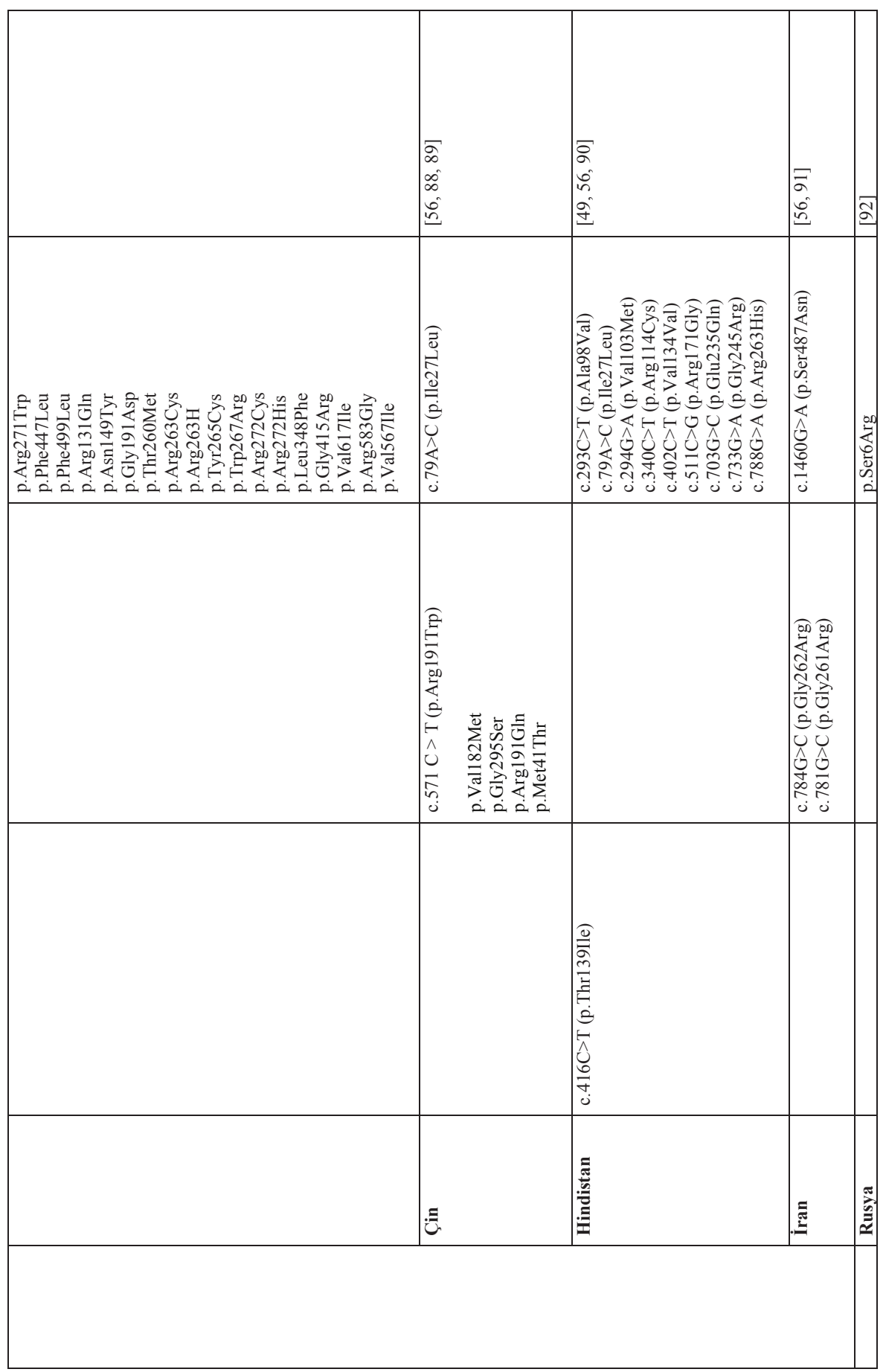




\section{Kaynaklar}

[1] Harikumar K., Kumar B.K., Hemalatha G.J., Kumar M.B. and Fransis S.L., A Review on Diabetes Mellitus, International Journal of Novel Trends in Pharmaceutical Sciences, Jun; 5(3), (2015), 201-207. ISSN: 2277 - 2782.

[2] Tattersall R.B., Mild familial diabetes with dominant inheritance, Q J Med., Apr;43 (170), (1974), 339-357.

[3] McDonald, T.J. and Ellard, S., Maturity onset diabetes of the young: identification and diagnosis, Annals of Clinical Biochemistry, 50(5), (2013), 403-415.

[4] Agarwal S.K., Khatri S., Prakash N., Singh N.P., Anuradha S. and Prakash A., Maturity Onset Diabetes of Young, JIACM, 3(3), (2002), 271-277.

[5] Bosma, A.R., Rigter, T., Weinreich, S.S., Cornel, M.C. and Henneman, L., A genetic diagnosis of maturity-onset diabetes of the young (MODY): experiences of patients and family members, Diabet Med, 32(10), (2015), 1385-1392.

[6] Gardner, D.S. and Tai, E.S., Clinical features and treatment of maturity onset diabetes of the young (MODY), Diabetes Metab Syndr Obes, 5, (2012), 101108. doi:10.2147/DMSO.S23353

[7] Nakhla, M. and Polychronakos, C., Monogenic and Other Unusual Causes of Diabetes Mellitus, Pediatric Clinics of North America, 52, (2005), 1637- 1650.

[8] Ovysyannikova A.K., Rymar O.D., Shakhtshneider E.V., Klimontov V.V., Koroleva E.A, et al., ABCC8-Related Maturity-Onset Diabetes of the Young (MODY12): Clinical Features and Treatment Perspective, Diabetes Ther., Sep;7(3), (2016), 591-600. doi: 10.1007/s13300-016-0192-9. Epub 2016 Aug 18.

[9] Oliveira, S.C., Neves, J.S., Perez, A. and Carvalho, D., Maturity-onset diabetes of the young: From a molecular basis perspective toward the clinical phenotype and proper management, Endocrinol Diabetes Nutr., 67(2), (2020), 137-147.

[10] Atabek, M.E. ve Kurtoglu, S., Gençlerin Erişkin Başlangıçlı Diabeti, Turkish Journal Of Medical Sciences, 24, (2004), 167-172.

[11] Fajans, S.S., Scope and Heterogeneous nature of MODY, Diabetes Care, 13, (1990), 49-64.

[12] Kahn, C.R., Weir, G.C., King, G.L., Moses, A.C., Smith, R.J. and Jacobson, A.M., Joslin's Diabetes mellitus, 14. Bask1. Chapter 22: Genetics of Type 2 Diabetes, 371-392, Lippincott Williams and Wilkins, (2005).

[13] Vaxillaire, M. and Froguel, P., Monogenic Diabetes in the Young, Pharmacogenetics and Relevance to Multifactorial Forms of Type 2 Diabetes. Endocrine Reviews, 29(3), (2008), 254-264. 
[14] Thanabalasingham, R. and Owen, K.R., Diagnosis and management of maturity onset diabetes of the young (MODY), BMJ, 343 (2011), d6044. doi: 10.1136/bmj.d6044

[15] Kim, S.H., Maturity-onset diabetes of the young: what do cli $\neg$ nicians need to know?, Diabetes Metab J., 39, (2015), 468-77.

[16] Prudente, S., Jungtrakoon, P., Marucci, A., Ludovico, O., Buranasupkajorn, P., et al., Loss-of-Function Mutations in APPL1 in Familial Diabetes Mellitus, Am J Hum Genet, 97(1), (2015), 177-185. doi:10.1016/j.ajhg.2015.05.011

[17] Nkonge, K.M., Nkonge, D.K. and Nkonge, T.N., The epidemiology, molecular pathogenesis, diagnosis, and treatment of maturity-onset diabetes of the young (MODY), Clinical Diabetes and Endocrinology, 6, (2020), 20.

[18] Ellard, S., Bellanne-Chantelot, C., Hattersley, A.T, and European Molecular Genetics Quality Network (EMQN) MODY group, Best practice guidelines for the molecular genetic diagnosis of maturity-onset diabetes of the young, Diabetologia, Apr; 51(4), (2008), 546-53. [PubMed: 18297260]

[19] Juszczak, A. and Owen, K., Identifying subtypes of monogenicdiabetes, Diabetes Manage, 4(1), (2014), 49-61.

[20] Kleinberger, J.W. and Pollin, T.I., Undiagnosed MODY: Time for Action. Curr Diab Rep., 15(12), (2015), 110. doi:10.1007/s11892-015-0681-7

[21] Dusatkova, P., Fang, M., Pruhova, S., Gjesin, A.P., Cinek, O., et al., Lessons from whole-exome sequencing in MODYX families, Diabetes and Clinical Practice, 104, (2014), e72-e74.

[22] Kawakita, R., Hosokawa, Y., Fujimaru, R., Tamagawa, N., Urakami, T., et al., Molecular and clinical characterization of glucokinase maturity-onset diabetes of the young (GCK-MODY) in Japanese patients, Diabet Med., Nov; 31(11), (2014), 1357-62. [PubMed: 24804978]

[23] Moghbeli, M., Naghibzadeh, B., Ghahraman, M., Fatemi, S., Taghavi, M., et al., Mutations in HNF1A Gene are not a Common Cause of Familial Young-Onset Diabetes in Iran, Ind J Clin Biochem, 33(1), (2018), 91-95.

[24] Cho, E.H., Min, J.W., Choi, S.S., Choi, H.S. and Kim, S.W., Identification of Maturity-Onset Diabetes of the Young Caused by Glucokinase Mutations Detected Using Whole-Exome Sequencing, Endocrinol Metab (Seoul), 32(2), (2017), 296-301. doi:10.3803/EnM.2017.32.2.296

[25] Hwang, J.S., Shin, C.H., Yang, S.W., Jung, S.Y. and Huh, N., Genetic and clinical characteristics of Korean maturity-onset diabetes of the young (MODY) patients, Diabetes Res Clin Pract, 74(1), (2006), 75-81. doi:10.1016/j.diabres.2006.03.002 
[26] Xu, J.Y., Dan, Q.H, Chan, V., Wat, N.M., Tam, S., et al., Genetic and clinical characteristics of maturity-onset diabetes of the young in Chinese patients, Eur J Hum Genet, 13, (2005), 422-427.

[27] Zhang, M., Zhou, J.J., Cui, W., Li, Y., Yang, P., et al., Molecular and phenotypic characteristics of maturity-onset diabetes of the young compared with early onset type 2 diabetes in China, Journal of Diabetes, 7, (2015), 858-863.

[28] Horikawa, Y., Hosomichi, K., Enya, M., Ishiura, H., Suzuki, Y., et al., No novel, high penetrant gene might remain to be found in Japanese patients with unknown MODY, Journal of Human Genetics, (2018), https://doi.org/10.1038/ s10038-018-0449-4

[29] Zhang, J., Li, L., Jiang, Y., Lu, M., Chen, Y., et al., The first E59Q mutation identified in the NEUROD1 gene in a Chinese family with maturity-onset diabetes of the young, Journal of Bio-X Research, (2020), http://dx.doi. org/10.1097/JBR.0000000000000065

[30] Iwasaki, N., Oda, N., Ogata, M., Hara, M., Hinokio, Y., et al., Mutations in the hepatocyte nuclear factor-1alpha/MODY3 gene in Japanese subjects with early- and late-onset NIDDM, Diabetes, 46, (1997), 1504-1508.

[31] Nishigori, H., Yamada, S., Kohama, T., Utsugi, T., Shimizu, H., et al., Mutations in the hepatocyte nuclear factor-1á gene (MODY3) are not a major cause of early-onset non-insulin-dependent (type 2) diabetes mellitus in Japanese, J Hum Genet., 43, (1998), 107-110.

[32] Tonooka, N., Tomura, H., Takahashi, Y., Onigata, .K, Kikuchi, N., et al., High frequency of mutations in the HNF-1alpha gene in non-obese patients with diabetes of youth in Japanese and identification of a case of digenic inheritance, Diabetologia, 45, (2002), 1709-1712.

[33] Jang, K.M., Maturity-onset diabetes of the young: update and perspectives on diagnosis and treatment, Yeungnam Univ J Med, 37(1), (2020), 13-21. https:// doi.org/10.12701/yujm.2019.00409

[34] Urakami, T., Maturity-onset diabetes of the young (MODY): current perspectives on diagnosis and treatment, Diabetes, Metabolic Syndrome and Obesity: Targets and Therapy, 12, (2019), 1047-1056.

[35] Park, S.S., Jang, S.S., Ahn, C.H., Kim, J.H., Jung, H.S., et al., Identifying pathogenic variants of monogenic diabetes using targeted panel sequencing in an east Asian population, J Clin Endocrinol Metab, (2019), jc.2018-02397.

[36] Tanaka, D., Nagashima, K., Sasaki, M., Funakoshi, S., Kondo, Y., et al., Exome sequencing identifies a new candidate mutation for susceptibility to diabetes in a family with highly aggregated type 2 diabetes, Mol Genet Metab, 109, (2013), $112-117$. 
[37] Shim, Y.J., Kim, J.E., Hwang, S.K., Choi, B.S., Choi, B.H., et al., Identification of candidate gene variants in Korean MODY families by whole-exome sequencing, Horm Res Paediatr, 83, (2015), 242-251.

[38] Bonatto, N., Nogaroto, V., Svidnicki, P.V., Milléo, F.Q., Grassiolli, S., et al., Variants of the HNF1A gene: A molecular approach concerning diabetic patients from southern Brazil, Genetics and Molecular Biology, 35(4), (2012), 737-740.

[39] Johansson, S., Irgens, H., Chudasama, K.K., Molnes, J., Aerts, J., et al., Exome sequencing and genetic testing for MODY, PLoS One, 7, (2012), e38050.

[40] Fajans, S.S., Bell, G.I. and Polonsky, K.S., Molecular mechanisms and clinical pathophysiology of maturity-onset diabetes of the young, N Engl J Med, 345, (2001), 971-980.

[41] Mohan, V., Radha, V., Nguyen, T.T., Stawiski, E.W., Pahuja, K.B., et al., Comprehensive genomic analysis identifies pathogenic variants in maturity-onset diabetes of the young (MODY) patients in South India, BMC Medical Genetics, 19, (2018), 22.

[42] Yalçın Çapan, Ö., Aydın, N., Yılmaz, T. and Berber, E., Whole exome sequencing reveals novel candidate gene variants for MODY., Clinica Chimica Acta, 510, (2020), 97-104.

[43] Anik, A., Catli, G., Abaci, A., Sari, E., Yesilkaya, E., et al., Molecular diagnosis of maturity-onset diabetes of the young (MODY) in Turkish children by using targeted next-generation sequencing, J Pediatr Endocrinol Metab, 28(11-12), (2015), 1265-1271. doi:10.1515/jpem-2014-0430

[44] Bozkurt, S., Arıkoğlu, H., Baldane, S. and İşcioğlu, F., Gestasyonel diyabet gelişiminde KCNJ11 geninin rolü, Genel Tip Derg, 25, (2015), 116-121.

[45] Haliloglu, B., Hysenaj, G., Atay, Z., Guran, T., Abali, S., et al., GCK gene mutations are a common cause of childhood-onset MODY (maturity-onset diabetes of the young) in Turkey, Clin Endocrinol (Oxf), 85(3), (2016), 393-399. doi:10.1111/cen.13121

[46] Karaca, E., Onay, H., Cetinkalp, S., Aykut, A., Goksen, D., et al., The spectrum of HNF1A gene mutations in patients with MODY 3 phenotype and identification of three novel germline mutations in Turkish Population, Diabetes Metab Syndr,11S, (2017), 491-496. doi:10.1016/j.dsx.2017.03.042

[47] Aykut, A., Karaca, E., Onay, H., Goksen, D., Cetinkalp, S., et al., Analysis of the GCK gene in 79 MODY type 2 patients: A multicenter Turkish study, mutation profile and description of twenty novel mutations, Gene, 641, (2018), 186189. doi:10.1016/j.gene.2017.10.057

[48] Karaoğlan, M. and Nacarkahya, G., Clinical and laboratory clues of maturity-onset diabetes of the young and determination of association with molecular diagnosis, Journal of Diabetes. (2020), 1-10. DOI: 10.1111/17530407.13097 
[49] Anuradha, S., Radha, V. and Mohan, V., Association of novel variants in the hepatocyte nuclear factor 4A gene with maturity onset diabetes of the young and early onset type 2 diabetes, Clinical Genetics, Dec, 80(6), (2011 ), 541-9. [PubMed: 21062274]

[50] Awa, W.L., Schober, E., Wiegand, S., Herwig, J., Meissner, T., et al., Reclassification of diabetes type in pediatric patients initially classified as type 2 diabetes mellitus: 15 years follow-up using routine data from the German/Austrian DPV database, Diabetes Research and Clinical Practice, 94, (2011), 463 - 467.

[51] Yorifuji, T., Fujimaru, R., Hosokawa, Y., Tamagawa, N., Shiozaki, M., et al., Comprehensive molecular analysis of Japanese patients with pediatric-onset MODY-type diabetes mellitus, Pediatric Diabetes, Feb; 13(1), (2012), 26-32. [PubMed: 22060211]

[52] Alvelos, M.I., Rodrigues, M., Lobo, L., Medeira, A., Sousa, A.B., et al. Novel Mutation of the HNF1B Gene Associated With Hypoplastic Glomerulocystic Kidney Disease and Neonatal Renal Failure, Medicine, 94(7), (2015), e469. DOI: 10.1097/MD.0000000000000469

[53] Covantev, S., Chiriac, A., Perciuleac, L. and Zozina, V., Maturity onset diabetes of the young: Diagnosis and treatment options, 5(4), (2016), e0402 DOI: 10.15275/rusomj.2016.0402

[54] İşleyen, F. ve Bolu, S., Adıyaman İlindeki Diyabetik Çocukların Epidemiyolojik Özellikleri, JCP, 17(1), (2019), 1-16.

[55] Billings, L.K., Jablonski, K.A., Warner, A.S., Cheng, Y.-C., McAteer, J.B., et al., The Journal of Clinical Endocrinology \& Metabolism, August, 102(8), (2017), 2678-2689. doi: 10.1210/jc.2016-3429

[56] Kanca-Demirci, D., Gençlerin Erişkin Başlangıçlı Diyabetinde (MODY) Türk Populasyonunda Hedef Genetik Profilin Araştırılması, Yüksek Lisans Tezi, İstanbul Üniversitesi, Aziz Sancar Deneysel Tıp Araştırma Enstitüsü, (2018).

[57] Aguilar-Salinas, C.A., Reyes-Rodriguez, E., Ordonez-Sanchez, M.L., Torres, M.A., Ramirez-Jimenez, et al., Early-onset type 2 diabetes: metabolic and genetic characterization in the Mexican population, The Journal of Clinical Endocrinology \& Metabolism, 86; (2001), 220-226.

[58] McKinney, J.L., Cao, H., Robinson, J.F., Metzger, D.L., Cummings, E., et al., Spectrum of HNF1A and GCK mutations in Canadian families with maturity-onset diabetes of the young (MODY), Clinical and Investigative Medicine, 27(3), (2004), 129-34.

[59] Giuffrida, F.M.A., Moises, R.S., Weinert, L.S., Calliari, L.E., Manna, T.D., et $a l$., Maturity-onset diabetes of the young (MODY) in Brazil: Establishment of a national registry and appraisal of available genetic and clinical data, Diabetes research and clinical practice, 123, (2017), 134-142. 
[60] Pearson, E.R., Pruhova, A., Tack, C.J., Johansen, A., Castleden, H.A., et al., Molecular genetics and phenotypic characteristics of MODY caused by hepatocyte nuclear factor 4-alpha mutations in a large European collection, Diabetologia, 48, (2005), 878-885.

[61] Ellard, S. and Colclough, K., Mutations in the Genes Encoding the Transcription Factors Hepatocyte Nuclear Factor 1 Alpha (HNF1A) and 4 Alpha (HNF4A) in Maturity-Onset Diabetes of the Young, Human Mutation, 27(9), (2006), 854-869.

[62] Osbak, K.K., Colclough, K., Saint-Martin, C., Beer, N.L., Bellanne'-Chantelot, C., et al., Update on Mutations in Glucokinase (GCK), Which Cause Maturity-Onset Diabetes of the Young, Permanent Neonatal Diabetes, and Hyperinsulinemic Hypoglycemia, Human Mutation, 30, (2009), 1512-1526.

[63] Colclough, K., Bellanne-Chantelot, C., Saint-Martin, C., Flanagan, S.E., and Ellard, S., Mutations in the Genes Encoding the Transcription Factors Hepatocyte Nuclear Factor 1 Alpha and 4 Alpha in Maturity-Onset Diabetes of the Young and Hyperinsulinemic Hypoglycemia, Human Mutation, 34, (2013), 669-685.

[64] Lindner, T., Gragnoli, C., Furta, H., Cockburn, B.N., Petzold, C., et al., Hepatic Function in a Family with a Nonsense Mutation (R154X) in the Hepatocyte Nuclear Factor-4a/MODY1 Gene, The Journal of Clinical Investigation, 100, (1997), 1400-1405.

[65] Lausen, J., Thomas, H., Lemm, I., Bulman, M., Borgschulze, M., et al., Naturally occurring mutations in the human HNF4A gene impair the function of the transcription factor to a varying degree, Nucleic Acid Research, 28(2), (2000), 430-437.

[66] Toaima, D., Nake, A., Wendenburg, J., Praedicow, K., Rohayem, J., et al., Mutations and Polymorphisms in German Families with Maturity-Onset Diabetes of the Young (MODY), Human Mutation Mutation in Brief, 805, (2005), Online. DOI: 10.1002/humu.9334

[67] Pruhova, S., Dusatkova, P., Sumnik, Z., Kolouskova, S., Pedersen, O., et al., Glucokinase diabetes in 103 families from a country-based study in the Czech Republic: geographically restricted distribution of two prevalent GCK mutations, Pediatric Diabetes, 11, (2010), 529-535.

[68] Moller, A.M., Dalgaard, L.T., Ambye, L., Hansen, L., Schmitz, O., et al., A Novel Phe75fsdelT Mutation in the Hepatocyte Nuclear Factor-4a Gene in a Danish Pedigree with Maturity-Onset Diabetes of the Young, The Journal of Clinical Endocrinology \& Metabolism, 84, (1999), 367-369. 
[69] Johansen, A., Ek, J., Mortensen, H.B., Pedersen, O. and Hansen, T., Half of Clinically Defined Maturity-Onset Diabetes of the Young Patients in Denmark Do Not Have Mutations in HNF4A, GCK, and TCF1, The Journal of Clinical Endocrinology \& Metabolism, 90(8), (2005), 4607-4614.

[70] Chevre, J.C., Hani, E.H., Boutin, P., Vaxillaire, M., Blanch, H., et al., Mutation screening in 18 Caucasian families suggest the existence of other MODY genes, Diabetologia, 41, (1998), 1017-1023.

[71] Bellanne-Chantelot, C., Carette, C., Riveline, J.P., Valero, R., Gautier, J.F., et $a l$., The type and the position of HNF1A mutation modulate age at diagnosis of diabetes in patients with maturity-onset diabetes of the young (MODY)-3, Diabetes, 57(2), (2008), 503-508. doi:10.2337/db07-0859

[72] Barrio, R., Bellanne-Chantelot, C., Moreno, J.C., Morel, V., Calle, H., et al., Nine novel mutations in maturity-onset diabetes of the young (MODY) candidate genes in 22 Spanish families, The Journal of Clinical Endocrinology \& Metabolism, 87(6), (2002), 2532-2539. doi:10.1210/jcem.87.6.8530

[73] Estalella, I., Rica, I., Perez de Nanclares, G., Bilbao, J.R., Vazquez, J.A., et al., Mutations in GCK and HNF-1 alpha explain the majority of cases with clinical diagnosis of MODY in Spain, Clinical Endocrinology (Oxf), 67(4), (2007), 538-546. doi:10.1111/j.1365-2265.2007.02921.x

[74] Mantovani, V., Salardi, S., Cerreta, V., Bastia, D., Cenci, M., et al., Identification of Eight Novel Glucokinase Mutations in Italian Children with Maturity-Onset Diabetes of the Young, Human Mutation, 650, (2003), 6 pages.

[75] Lorini, R., Klersy, C., d’Annunzio, G., Massa, O., Minuto, N., et al., Maturity-onset diabetes of the young in children with incidental hyperglycemia: a multicenter Italian study of 172 families, Diabetes Care, 32(10), (2009), 18641866. doi:10.2337/dc08-2018

[76] Delvecchio, M., Ludovico, O., Menzaghi, C., Di Paola, R., Zelante, L., et al., Low prevalence of HNF1A mutations after molecular screening of multiple MODY genes in 58 Italian families recruited in the pediatric or adult diabetes clinic from a single Italian hospital, Diabetes Care, 37(12), (2014), e258-260. doi:10.2337/dc14-1788

[77] Bjorkhaug, L., Sagen, J.V., Thorsby, P., Sovik, O., Molven, A. and Njolstad, P.R., Hepatocyte nuclear factor-1 alpha gene mutations and diabetes in Norway, The Journal of Clinical Endocrinology \& Metabolism, 88(2), (2003), 920-931.

[78] Sagen, J.V., Bjorkhaug, L., Molnes, J., Raeder, H., Grevle, L., et al., Diagnostic screening of MODY2/GCK mutations in the Norwegian MODY Registry, Pediatr Diabetes, 9(5), (2008), 442-449. doi:10.1111/j.1399-5448.2008.00399.x

[79] Sovik, O., Irgens, H.U., Molnes, J., Sagena, J.M., Bjorkhaug, L., et al., Monogenic diabetes mellitus in Norway, Norwegian Journal of Epidemiology, 23(1), (2013), 55-60. 
[80] Tatsi, C., Kanaka-Gantenbein, C., Vazeou-Gerassimidi, A., Chrysis, D., Delis, D., et al., The spectrum of HNF1A gene mutations in Greek patients with MODY3: relative frequency and identification of seven novel germline mutations, Pediatric Diabetes, 14, (2013), 526-534. doi: 10.1111/pedi.12032

[81] Tatsi, E.B., Kanaka-Gantenbein, C., Scorilas, A., Chrousos, G.P. and Sertedaki, A., Next generation sequencing targeted gene panel in Greek MODY patients increases diagnostic accuracy, Pediatric Diabetes, 21, (2020), 28-39.

[82] Almeida, C., Silva, S.R.S., Garcia, E., Leite, A.L., Teles, A. and Campos, R.A., A novel genetic mutation in a Portuguese family with GCK-MODY, Journal of Pediatric Endocrinology and Metabolism, 27(1-2), (2014), 129-133. DOI 10.1515/jpem-2013-0056

[83] de Mafra, J.P. de M.G., Clinical and molecular characterization of Portuguese patients with a clinical diagnosis of MODY, Master Thesis, Universidade De Lisboa, Faculdade De Ciências, Departamento De Biologia Vegetal, (2017).

[84] Bonnycastle, L.L., Willer, C.J., Conneely, K.N., Jackson, A.U. Burril, C.P., et al., Common Variants in Maturity-Onset Diabetes of the Young Genes Contribute to Risk of Type 2 Diabetes in Finns, Diabetes, 55, (2006), 2534-2540.

[85] Tuhan, H.Ü., Anık, A., Çatlı, G., Kızıldağ, S, Abacı, A. ve Böber E., Çocukluk Çağında Diyabetin Nadir Bir Nedeni: Glukokinaz Mutasyonu (MODY2), Türkiye Aile Hekimliği Dergisi, 18 (2), (2014), 110-112.

[86] Yılmaz-Ağladığlu, S., Aycan, Z., Çetinkaya, S., Baş, V.N., Önder, A., et al., Maturity onset diabetes of youth (MODY) in Turkish children: sequence analysis of 11 causative genes by next generation sequencing, Journal of Pediatric Endocrinology and Metabolism, 29(4), (2016), 487-496.

[87] Horikawa, Y., Enya, M., Fushimi, N., Fushimi, Y. and Takeda, J., Screening of diabetes of youth for hepatocyte nuclear factor 1 mutations: clinical phenotype of HNF1beta-related maturity-onset diabetes of the young and HNF1 alpha-related maturity-onset diabetes of the young in Japanese, Diabetic Medicine, 31(6), (2014), 721-727. doi:10.1111/dme.12416

[88] Xiao, Y.P., Xu, X.H.X., Fang, Y.I., Jiang, L., Chen, C., et al., GCK mutations in Chinese MODY2 patients: a family pedigree report and review of Chinese literatüre, J Pediatr Endocrinol Metab, 29(8), (2016), 959-964.

[89] Li, X., Ting, T.H., Sheng, H., Liang, C.,L., Shao, Y., et al., Genetic and clinical characteristics of Chinese children with Glucokinase maturity-onset diabetes of the young (GCK-MODY), BMC Pediatrics, 18, (2018), 101. https://doi. org/10.1186/s12887-018-1060-8

[90] Radha, V., Ek, J., Anuradha, S., Hansen, T., Pedersen, O. and Mohan, V., Identification of Novel Variants in the Hepatocyte Nuclear Factor-1 Gene in South Indian Patients with Maturity Onset Diabetes of Young, The Journal of Clinical Endocrinology \& Metabolism, 94, (2009), 1959-1965. 
[91] Moghbeli, M., Naghibzadeh, B., Ghahraman, M., Fatemi, S., Taghavi, M., et al., Mutations in HNF1A Gene are not a Common Cause of Familial Young-Onset Diabetes in Iran, Indian Journal of Clinical Biochemistry, 33(1), (2018), 9195.

[92] Ovsyannikova, A.K., Rymar, O.D., Ivanoshchuk, D.E., Mikhailova, S.V. and Shakhtshneider, E.V., A Case of Maturity Onset Diabetes of the Young (MODY3) in a Family with a Novel HNF1A Gene Mutation in Five Generations, Diabetes Therapy, 9, (2018), 413-420. https://doi.org/10.1007/s13300017-0350-8 